\title{
Analysing the Asymmetry in Decentralised International Co-operation: The Case of Brazil/Europe Sub-national Relations
}

\author{
Liliana Ramalho Froio* \\ Marcelo de Almeida Medeiros**
}

\begin{abstract}
The article analyses the decentralised international co-operation between Brazil and Europe, focusing on two specific issues that are not the main objectives of the literature specialised in paradiplomacy studies: first, how international co-operation can be used as a tool for power projection and second, the effects that the economic, political and institutional asymmetry among the actors involved in co-operation arrangements produces on the co-operation outcomes. For that, a wide range of documents and data was used (interviews, official documents, minutes of meetings and data collected with a survey applied to public managers) related to the international co-operation developed between Brazil and European countries. The conclusions are that even in decentralised co-operation arrangements, power relations matter to the results of co-operation.
\end{abstract}

Keywords: decentralised international co-operation; sub-national relations; asymmetry; Brazil; Europe.

'Nous ne coalison pas des États, nous unissons des hommes.' -Jean Monnet (1976: 7)

\section{Introduction}

It is remarkable that the participation of sub-national authorities in the international arena has become more intense in recent decades, particularly as a result of global interdependence, which has increased trans-sovereign contacts, as Ivo D. Duchacek (1990) points out. A globalised and interdependent world means greater mobility of people and

\footnotetext{
* Federal University of Paraíba (UFPB), João Pessoa-PB, Brazil; liliana.froio@gmail.com. ORCID iD 00000003-4117-7315.

** Federal University of Pernambuco (UFPE), Recife-PE, Brazil; marcelo.medeiros@ufpe.br. ORCID iD 00000001-8385-0358.
} 
easy access to information, thus (i) facilitating interaction between societies as well as (ii) transforming the traditional state-centric logic, which instigates other players to become involved in international relations. Thereon, borders have become more porous and sovereignty perforated by higher flows of people, goods and pollutants. In other words, national boundaries cannot always effectively protect countries and their sub-national units from external events (Duchacek, Latouche and Stevenson 1988).

Therefore, the impact of globalisation on sub-state actors' economic, political and social strategies leads them to initiate and receive trans-sovereign contacts even though their wealth and power goals remain primarily intra-sovereign. This interconnected international environment, combined with domestic factors, may intensify the need for and the frequency of contacts between non-central governments and foreign actors. The main domestic factor mentioned is the inefficiency of central governments in representing the subunits' interests in national foreign policy, leading them to bypass the central government mechanisms, maintaining informal and/or formal direct international contacts (Duchacek 1990; Duchacek, Latouche and Stevenson 1988; Soldatos 1990). In fact, it has been a puzzle for the governments to bring together the different interests within countries' foreign policy, since the sub-national units are so distinct from each other in so many ways (cultural, demographic, infrastructural, economic, political). In any case, given the lack of adequate channels of interaction and convergence for central and non-central governments in several countries, the sub-national units autonomously carry out their international relations.

Searching for alternatives to promote their development, regional and local governments have expanded their relationships with foreign actors - a phenomenon well known as paradiplomacy. ${ }^{1}$ Another useful concept worth mentioning is that of constituent diplomacy, set forth by Kincaid (1990: 74), which is considered 'to be a neutral descriptor, one that avoids the implication that the activities of constituent governments are necessarily inferior, ancillary, or supplemental to the high politics of nation-state diplomacy.' Decentralised international co-operation (DIC), or just decentralised co-operation (DC), is one type of paradiplomatic activity and a form of co-operation involving constituent or sub-national governments. There are many other types of international activities undertaken by such governments, such as international travel or missions to promote local enterprises; establishment of representative offices abroad; participation in multilateral organisations and international networks; or participation in bilateral programmes. Such international activities may reflect the local government's interest in implementing policies both for economic growth and for the welfare of the citizens. Regions and cities go abroad to look for investment, market access, and technology for modernisation; to build up the local business sector; to promote themselves as tourist destinations; to gain support for their own cultural development and language promotion; to rediscover and revitalise identities; to help nation-building; and to gain recognition and legitimacy (Duchacek 1990: 13-15; Keating 1999: 3-5).

Moreover, these activities can serve as a means for projecting power. Regions and cities position themselves for global competition and external promotion, which is due to 
economic and political needs or even to nationalist conflict at their borders, for example. The literature on global cities highlights that cities can act as 'control points, as powerful centres of economic and cultural authority within the contemporary world-system [...] as places that are able to generate and disseminate discourses and collective beliefs' (Knox 1995: 7-8). More than that, 'these cities perform functions of economic control, military domination, and ideological influence over other regions' (Grosfoguel 1995: 158). In this sense, international agreements can go further than establishing partnerships or underlining mutual co-operation between territories, as they can keep the subunits interlinked, intensifying the existing (political and economic) relations, strengthening the presence and interests of certain external actors, and decreasing the presence of others in a way that increases dependence and agenda interference, especially in cases where co-operation occurs under asymmetric conditions, as will be shown in this paper.

Loaeza (2014) raises the German policy in Latin America as a successful case of power projection through political and cultural influence rather than economic influence. German influence succeeded due to the local approval for its support in the transition from authoritarianism to democracy from the 1980s onwards. The political and cultural relations established ensured a German moral and political leadership-building. Moreover, foreign policy in Latin America has also been most represented by labour unions, NGOs and sub-national governments.

Another example of the abovementioned situation is protodiplomacy. Protodiplomacy constitutes the desire of a given territorial community to become an autonomous political entity. Thus, a sub-national diplomatic effort is set up to establish foreign links and obtain support for future secession and international recognition (McHugh 2015). Hence, power projection, persuasion or the ability to attract a sufficient number of supporters are the tools for obtaining such goals. For this reason, reports regarding power and influence practised by the subunits should be pointing to protodiplomacy as the most common example. Despite its importance, it is understood that other forms of power practice should also take place. Such is the case with knowledge regions, 'whose strategic relevance derives from the very nature of tacit knowledge production and dissemination', which is a powerful ingredient to pursue their interests and project identity (Neves 2010: 15).

In short, there are arguments, as shown by Loaeza (2014), that paradiplomatic tools could function as power projection in some situations. Setting the nuances of conceptual discussions aside, power has been generally understood as the ability of an actor to influence others into behaving differently than they normally would (Nye 2011: 6).

In this sense, this paper analyses if forms of power projection in Brazil-Europe sub-national co-operation have occurred, i.e. projection of interests and interference in the path of co-operation. The hypothesis is that the existing asymmetry between sub-national entities affected DIC, more precisely defining its agenda (agenda interference), which implies defining the issues that will be focused on and the choices that will be made throughout the co-operation process. The hypothesis comes from the general argument that DIC is a more horizontal type of co-operation, since it is not the same as conventional state diplomacy, which is about pursuing a defined state interest in the international arena' (Keating 
1999: 11). As it occurs between territorial entities that are at the same governmental level and have similar problems, the establishment of partnerships for the exchange of experiences could overcome common challenges. Thereby, in spite of the existing asymmetries (differences in terms of economic level, institutional capabilities, bureaucratic expertise, etc.), it is expected that DIC could be more equitable, aiming for mutual benefits rather than setting up hierarchical co-operation, as manifested by a sub-national government's agenda imposition. Although most of the literature does not consider the problem of asymmetry between subunits when analysing paradiplomacy, using Brazil-Europe sub-national relations as a case study, this article shows that asymmetry can impact DIC significantly.

The fundamental premise for the case study is that, even though from 2003 onwards Brazilian foreign policy has prioritised South-South co-operation, some European countries have, over the past decade, conjectured their own prominence as Brazil's partners. This may be so because of the co-operation with Brazilian sub-national entities (state government), among other reasons. It is also worth mentioning the increase in paradiplomatic actions in Brazil, particularly since 1990, the intensive and larger-scale use of DC by European countries as a standard practice, and the increasing cases of DC between Brazil and Europe in recent years. So, considering these elements, the paper's goal is not to describe the behaviour of actors (or depict the relational dimension of power), but to evaluate the DC between Brazil and Europe, assessing how it can be a way to exercise influence and, thus, power.

The study departs from the literature on asymmetric international co-operation and examines a case of North-South paradiplomatic co-operation. The analysis is based on the literature's explanations and empirical research on Brazil/Europe DIC from 1999 to 2014. The materials and data used were: interviews with officials of Brazilian states; bilateral projects of international technical co-operation signed between the Brazilian states and some European countries in the period between 1999 and 2014 (273 projects obtained from the Brazilian Cooperation Agency of the Ministry of Foreign Affairs - ABC/MRE); a survey sent by e-mail to officials from all Brazilian states (199 questionnaires answered); and documents from meetings about DIC (2013-2014) organised by the Under Secretariat for Federative Affairs of the Presidency of the Republic of Brazil. The article shows the impact of asymmetry on DIC between Brazil and European countries. Then, it is divided into three sections, plus an introduction and a conclusion: (i) in the first section, we present the origins and concept of DIC; (ii) secondly, we address asymmetric international co-operation studies, first on North-South co-operation within the field of international co-operation for the development and then the discussions on asymmetry and power projection in the literature on paradiplomacy; (iii) in the last section, we analyse a case of asymmetry within the DIC between Brazil and Europe, showing the differences in paradiplomacy of Brazil and Europe and how the European countries have projected power and defined the DIC agenda (agenda interference). 


\section{Decentralised international co-operation: origins and definitions}

The global context of increased interdependence between countries and some limitations of countries' ability to represent sub-national governments internationally have fuelled a growing interest and the direct participation of sub-national authorities in international affairs. Consequently, this brought about new theories and research agendas for the academic field of International Relations (IR), exploring the diversification of actors in international politics. These studies sought to question the theoretical and classical argument that the state is the only relevant actor in the international system. The focus fell on global interdependence and the emergence of new actors, particularly domestic actors and international institutions, such as agents who promote international co-operation and facilitate regional integration. As stated by Heine (2013: 56):

The logic of flows and of networks has had a double impact on the modern nation state. On the one hand, it has forced the state to give up a measure of its national sovereignty to link up with a variety of supra-national and intergovernmental units that attempt to introduce a measure of coordination among national policies. On the other hand, it has opened the 'black box' of the nation state, as many sub-national units and civil society actors link up with their own peers across the world, giving a further impetus to transnational relations. All of this has led to a growing number of actors, both domestic and international, and the always critical 'foreign policy community' to make their presence felt and to add layers of complexity to government decision-making, foreign policy, and the conduct of diplomacy.

The theoretical constructs in IR about global interdependence and the international role of new actors joined the studies on federalism, especially those discussions about the organisation, functioning, and territorial transformations of federal systems (Duchacek 1970, 1986; Elazar 1966, 1987). As pointed out by Elliot Feldman and Lily Feldman (1984: 34-36), although Keohane and Nye recognise that foreign policy is not the exclusive domain of central government foreign ministers, they underestimate the scope, magnitude and significance of transgovernmentalism and do not give greater attention to the functioning of the subunits. Hence, it was through the work of some European, Canadian and American political scientists that the international activity of sub-national government entities gained new meaning. In their research, they discussed the relationship between federalism, international relations and foreign policy, influenced by the works of Robert Keohane and Joseph Nye on interdependence and transnationalism.

Initially, these authors deal with several case studies on sub-national international relations, especially in industrialised countries like the USA and Canada. The latter was the starting point of the analysis, as it featured one of the most advanced cases of paradiplomacy, as a sub-national government aimed to establish a fully sovereign state through international actions. This was the case of the province of Quebec, which sought to use 
the contacts made with foreign governments as a form of preparatory diplomatic work for a future secession and its international recognition (Kuznetsov 2015). This strategy to promote the independence of the federal entity was named 'protodiplomacy' (Duchacek, Latouche and Stevenson 1988). Ivo Duchacek, who created the first subject terminologies and whose pioneering research identified and studied the new phenomenon, wrote most of the papers on the international role of sub-national governments at the time. Duchacek initially uses the term 'microdiplomacy' to define the relationship between subunits from different countries and 'macrodiplomacy' as traditional diplomacy of central governments. However, he later clarified that this terminology could acquire a derogatory image. For this reason, he adopted the term 'paradiplomacy', first put forth by Panayotis Soldatos. According to him, the term 'para' expresses the phenomenon more accurately: as a parallel activity, often coordinated, complementary and sometimes in conflict with the traditional diplomacy of central governments (Duchacek 1990: 32). The concept of paradiplomacy has become widely used since then, including by Brazilian scholars.

In short, it is noticeable how the monopoly of nation-states' central governments in conducting foreign affairs has been undermined over the years and how their territorial units have assumed the starring role in various negotiations, especially those that impact them directly. There are several strategies adopted by sub-national governments in their external relations. In general, paradiplomatic international instruments are classified according to their content and their obligatory character, as seen in the table below. DIC is a kind of paradiplomatic tool that is characterised by the establishment of a bilateral or multilateral partnership involving sub-national actors. Mónica Salomón (2012) asserts that the terms 'decentralised co-operation' and 'decentralised public co-operation' could also be used in the same way as DIC. However, it is relevant to note that literature is reluctant to define the concept strictly. Hafteck (2003) sought to point out conceptual differences, highlighting that DC is located at the intersection of two related fields: development aid co-operation and the international relations of sub-national governments.

It is possible to grasp that not all development co-operation and paradiplomacy consists of decentralised co-operation. The latter should involve sub-national governments (actors), aim for local development (goal) and focus on mutual exchange and support (nature). However, 'various organisations involved in development co-operation use and interpret the term in different ways' (Hafteck 2003: 334). The interpretation of the EU follows the 1995 Lomé Convention (later replaced by the 2000 Cotonou Agreement) and considers different entities to be agents of decentralised co-operation, since DC's actors are all possible project-implementing entities other than the central government that can execute DC as long as they engage in non-profit activities: 'A partnership between two universities, or two private foundations, or even two political parties could fall into the field of DC, according to the EU' (Hafteck 2003: 334). Others, like the United Nations Development Programme, interpret the matter differently, by stating that what matters is where activities take place. There is a geographical meaning in the concept, thus corresponding to international co-operation links between actors belonging to two sub-national geographical areas: 'These refer to areas of jurisdiction of specific local authorities, where the actors of DC are not necessarily the local authorities themselves' (Hafteck 2003: 334). 
Table 1 - General paradiplomatic tools.

\begin{tabular}{ll}
\hline Activity & Description \\
\hline Political representation abroad & $\begin{array}{l}\text { Signals the constituent unit's wishes to further } \\
\text { expand and deepen the existing co-operation } \\
\text { beyond the level of traditional diplomatic } \\
\text { relations or to facilitate contact with strategic } \\
\text { partners. Usually working closely with the } \\
\text { diplomacy of the central government. }\end{array}$ \\
\hline Treaty-making power & $\begin{array}{l}\text { Creates substantial content-based co-operation } \\
\text { with other partners. Builds and enhances the } \\
\text { international legal recognition of the respective } \\
\text { subunit. Depends on the legal power given to the } \\
\text { subunits or gained by them. }\end{array}$ \\
\hline Formal agreements & $\begin{array}{l}\text { Declarations of intent, memoranda of } \\
\text { understanding, co-operation agreements, } \\
\text { transnational contracts, cultural agreements } \\
\text { or partnerships. They are non-enforceable and } \\
\text { do not compel the contracting parties to follow } \\
\text { up on or implement their initial intention to } \\
\text { co-operate. Much more flexible compared to the } \\
\text { rather rigid structure of formal treaties. }\end{array}$ \\
\hline
\end{tabular}

Programmes of assistance and sharing of know-how

Bilateral programmes, programmes on cross-boundary co-operation, programmes that want to bring together the civil societies of the region and other regions/countries.

\begin{tabular}{|c|c|}
\hline Detachment & $\begin{array}{l}\text { Professional training - send out a limited number } \\
\text { of regional officials to work externally for a short } \\
\text { period of time in order to gain further experience. }\end{array}$ \\
\hline $\begin{array}{l}\text { Other forms of participation in multilateral } \\
\text { frameworks and organisations }\end{array}$ & $\begin{array}{l}\text { Observation of or participation in (technical) } \\
\text { committees, the creation of or participation } \\
\text { in funds within multilateral organisations, by } \\
\text { becoming an associate member of multilateral } \\
\text { organisations. Access to important multilateral } \\
\text { debates that affect their internal competencies. }\end{array}$ \\
\hline Participation in other formal and informal networks & $\begin{array}{l}\text { Attempt to set the international agenda, bring } \\
\text { the necessary know-how and actors together to } \\
\text { achieve specific goals, learn from other regions } \\
\text { with similar or different experiences. }\end{array}$ \\
\hline Developing a public diplomacy & $\begin{array}{l}\text { Personal or regional promotion. Publicity. Making } \\
\text { the international public more familiar with the } \\
\text { reputation of the region. }\end{array}$ \\
\hline $\begin{array}{l}\text { Subcontracting to associations, non-profit societies, } \\
\text { or third parties }\end{array}$ & $\begin{array}{l}\text { Attempt to utilise the know-how and networks of } \\
\text { societal groups to advance the policy goals. }\end{array}$ \\
\hline Political statements & $\begin{array}{l}\text { Attempt to have their voice heard. To position } \\
\text { themselves politically. }\end{array}$ \\
\hline Going abroad and foreign missions & $\begin{array}{l}\text { The means through which official contacts } \\
\text { are created and maintained. Trade promotion, } \\
\text { participation in international exhibitions, } \\
\text { technical visits, prospecting visits. }\end{array}$ \\
\hline
\end{tabular}

Source: Created by the authors, adapted from Criekemans (2008). 
Our understanding is closer to the view taken by France, Italy and the World Bank, in which DC takes place when sub-national governments make agreements or engage in programmes with foreign entities. In this sense, DC approaches DIC because co-operation necessarily involves constituent or sub-national governments. Some features of these perspectives can be emphasised, such as the importance of having a written agreement, the socioeconomic development goal along with the strengthening of skills and competencies of the partners involved, as well as the role of civil society. DC does not prohibit other agents from becoming involved in co-operation, and civil society is not only seen as a beneficiary but also as a protagonist. Hafteck finally summarises DC as a 'substantial collaborative relationship between sub-national governments from different countries, aiming at sustainable local development, implying some form of exchange or support carried out by these institutions or other locally based actor' (Hafteck 2003: 336).

This means that DC embraced a mutually beneficial relationship (as is the essence of co-operation), with the key involvement of civil society. Indeed, the terminology that appears at the end of the 1980s, within the Lomé Convention, was intended to review the traditional idea of co-operation in order to improve its applicability, efficiency, transparency and inspection (Salomón 2012: 10). This type of co-operation includes a wide range of actors who are more closely linked to the purpose of the projects, therefore promoting a more active participation on the part of the beneficiaries. To sum up, DC involves partnership, equality and mutuality. It is considered a more horizontal type of international co-operation, since it occurs between territorial entities that are at the same governmental level and that do not have the commitments required in countries' national diplomacy.

\section{The asymmetry in decentralised international co-operation}

Considering that DIC is a more horizontal type of co-operation, it is expected to have a non-hierarchical modus operandi, in which the partners can project interests equitably and get mutual benefits. However, what happens when DIC occurs between territories with asymmetric conditions? Can co-operation be used as a tool for power projection? Studies on international co-operation for development can guide the answers to these questions.

The practice of development co-operation began in the post-Second World War context through foreign assistance. Development assistance efforts, beginning in 1940s, were used as a mechanism for building spheres of influence. It was a traditional form of development co-operation based on a dyadic structure: donor countries and recipient countries. This structure reinforced a particular understanding that donor assistance (by development agencies or developed countries) could induce development in the Third World. However, besides not leading the countries into development, assistance was shown to be unfavourable to them:

Despite many changes over the past decades, the donor site was consolidated, and its ability to impose a particular set of goals for development practices was strengthened. Once they occupied the 
donor position, development agencies were authorised to speak and act on behalf of international development - that is, to lead recipient countries in the global South along a common development path. Although economic asymmetries were a sine qua non for the establishment of such a dyadic structure, the donor position was to be recognised by the recipients as an authoritative site in order to be consolidated. Donors should be able to rule the field and ascertain what to do and how to do it in order to achieve development and welfare (Esteves and Assunção 2014: 1778).

Thus, development assistance began to show weaknesses and evidence that asymmetry between donors and recipients would be reinforcing dependency rather than promoting development. Then the concept of assistance was surpassed by the countries of the South and replaced by the term 'development co-operation.' Unlike 'assistance,' 'co-operation' implies a relationship of mutual benefit, horizontality, greater participation and local control of resources. It also serves the political purpose of distinguishing the phenomenon that occurs in the South-South context of that found in the North-South. For the same reason, instead of using the concept of 'donor and recipient', the countries of the South refer to the countries involved in development co-operation as partners. In addition, South-South Co-operation (SSC) is distinctly characterised by the absence of so-called conditionalities, i.e. the imposition of conditions, mainly economic reforms, for lending or donations by international institutions or North countries (Mello e Souza 2014: 12). Such evidence on central government development co-operation can also be applied to sub-national governments in the context of DIC and serve as a guideline for the analysis of the impact of asymmetry on DIC and on paradiplomacy in general.

In this sense, a North-South DIC could also present interference and authority problems along the path of co-operation, similar to what we have in the development co-operation between central governments where asymmetry directly determines the situation. Such attitudes within DC would not be expected due to the characteristics of this type of co-operation (more horizontal, more equitable, aiming for mutual benefit), but our hypothesis is that asymmetry also affects this form of co-operation, defining its agenda and allowing the projection of power by territorial entities.

In the literature on paradiplomacy, the problem of asymmetry appears with another approach. Panayotis Soldatos (1990) was the first to pay attention to asymmetry. In Soldatos's view, asymmetry of federated units is a domestic cause of paradiplomacy. $\mathrm{He}$ points out that there are inherent challenges in decentralised political systems, where central governments must deal with the different interests and realities of subunits and the demands of local leaders, looking for ways to accommodate them and build a co-operative political system. However, territorial segmentation, which is characterised by the peculiarities of each subunit, such as geographical, cultural, linguistic, religious, economic and political factors, shows the many voices existing at all levels of government (different interests) and is a driving force - for subunits to participate directly in international affairs: 'segmentation may be heightened in the case of asymmetry of federated units', thus 
creating an even more attractive environment for sub-national governments' international involvement (Soldatos 1990: 46).

The constituent units have different levels of development that differentiate them in their international capability. The 'situation of the state in Brazilian federation, including regional or potential regional imbalances, constitutes a powerful force to push states into external relations' (Rodrigues 2004: 170). Asymmetry is therefore a condition, favourable or unfavourable, for governments to engage internationally. There are few references about the impact of asymmetry on co-operation itself. It is known that (i) paradiplomacy can be used to project power and influence and (ii) asymmetry generates unequal conditions for co-operation; however, a causal relationship between these two assumptions is not found in the literature.

Asymmetric international co-operation, such as North-South co-operation, can become assistance, opening space for competition and for vulnerability and, in a deeper way, for control and influence of the developed regions. It's nothing new that traditional strategies to become a global player imply being a 'leader in diplomacy, a generous aid donor, and a firm supporter of multilateral rules for regulating trade and international financial flows [...] Much assistance has been of dubious value, a result of the predominance in some donor countries of commercial or political interests that have little or nothing to do with development' (Freres 2000: 63, 67). In addition, sub-national actors, as well as states, are now also applying these strategies internationally. Thus, DIC can certainly serve as a means for power projection. According to Michele Acuto (2013: 482), the 'need to pay attention to city leaders, then, becomes even more crucial, given the growing interest in recuperating cities for international political purposes.' The political interests of subunits may involve, for example, the recognition of nationalist aspirations, the projection of regional politicians themselves, interference in other countries to mobilise resources, and influencing public opinion in key foreign countries (Keating 1999: 5-6).

The growth of cities' transnational influence has occurred mainly because of mayors' self-appointment to the central stage of global policymaking and the diplomacy of these cities, besides representing interests, may produce new engagements and redesign national, regional, and local spaces (Acuto 2013: 490). For instance, it is worth reporting the case of Cités Unies France, an organisation created in 1975 out of the World Federation of Twin Cities that has a 'membership of 500 local authorities at all levels of the French decentralised structure, and a network of some 2000 cities in France and in low - and middle-income countries' (Stren 2008: 388). The French central government called attention as it supported the initiative of its subunits. The document 'Governance Strategy for French Development Assistance' from the French Ministry of Foreign Affairs emphasises the importance of working with local authorities on overseas projects to develop exchanges with local government through the various representative bodies in existence (Stren 2008). In other words, it is one more alternative to benefit from the establishment of strategic partnerships and from the strengthening of alliances. This is an example of the impact that DC can provide, whereby states gain visibility, strengthen their leadership position and project values that form part of their image, as they develop the ability to 
affect others to obtain the outcomes one wants through attraction rather than coercion or payment' (Nye 2008: 94).

Josep Coll (2015) goes further by stating that emerging cities adopt a more efficient model than nation states, once their governance is better adapted to the reality of a fluid and unstable society. Cities are shaping a new global governance, attracting and dealing with various actors previously under the orbit of the nation-states.

Cities devote policies and resources to systematically foster cooperation with other cities based on a city-to-city exchange approach that may hold relevant for some global issues and many local issues of global reach. City cooperation represents an innovation in the process whereby knowledge is openly shared, transferred and applied by different cities for the sake of their own development (Coll 2015: 2).

This model of governance operates behind the scenes of macro politics, and its influence and implications are what we want to understand. Our contribution to these reflections will be made by analysing the case of DC between Brazil and Europe.

\section{Analysing Brazil/Europe sub-national relations}

In order to understand the asymmetry problem in DC between Brazil and Europe, we start by presenting some differences in the paradiplomatic environment of the countries.

In Europe, the international autonomy of subunits became a more prominent issue in the 1990s, as a result of the European integration process and the creation of the Committee of Regions. Furthermore, David Criekemans (2008) assumes that the diplomacy of sub-states is undergoing a 'third wave', especially in Europe. The first wave occurred in the 1980s, when an increasing number of non-central governments tried to attract foreign direct investment or to use cultural elements for international recognition. The second wave, in the 1990s, was marked by the institutionalisation of subunits' diplomatic activities, both in legal and administrative terms. Lastly, the third wave means advances in diplomatic tools and structural reorganisation, i.e. improvement of the paradiplomacy apparatus.

In Brazil, democratisation in the 1980s resulted in political changes in the federal system, from the transfer of powers to states and municipal governments. The Federal Constitution of 1988 deepened the autonomy of states and municipalities in various subjects; however, it retained the exclusive competence of the Brazilian central government to manage foreign affairs and to conclude international acts (Brazil 1988: Article 21). However, the absence of constitutional provision has not inhibited local governments from acting internationally. Some examples of this kind of sub-national international activities are missions abroad, fundraising, trade promotion and the establishment of international co-operation. It is argued that paradiplomacy can do without international legal norms and is legitimate insofar as it relates to matters over which the subunits have constitutional authority. 
Indeed, Brazilian paradiplomacy has been gaining strength in recent years. For this reason, the federal government has been concerned about their increased strength and has taken steps to respond to the phenomenon. Meanwhile, states and municipalities have been working in their areas of competence and using their constitutional guarantees to increase their international activities. Nevertheless, Brazil has yet to advance. In Europe, for instance, many European countries have internal rules that guarantee the international participation of subunits. Moreover, the subunits can be represented in supra-national EU bodies. For Brazilian subunits, such recognition is still inconceivable. Even the manner in which subunits conduct international relations and the instruments they use to act abroad serve as evidence of this disparity.

The treaty-making power depends on the degree of autonomy that is granted to subunits. The subunits of some federations have the competence to conclude international treaties and contract obligations on the international scene, an attribution that confers the condition of full subjects of law on them. Such is the case of the German Länder and Belgian regions (Jones and Keating 1995). In other federations, however, the authorities have limited capacity in international legal terms. Brazilian states and municipalities are not allowed to make treaties. Such attribution is exclusively granted to the central government and, thus, forbidden to federated entities. Even formal agreements must be referred to the Ministry of Foreign Affairs. The guidelines of the Brazilian Cooperation Agency of the Ministry of Foreign Affairs (ABC-MRE) state that only the central government has the authority to sign international agreements on technical co-operation, especially due to the commitment of these acts. States and municipalities must accept ABC-MRE mediation if they intend to establish a partnership in the field of technical co-operation, be it with an international organisation or a foreign government.

Brazilian subunits do not tend to establish political representation abroad. The mechanisms they most commonly use include participation in networks, formal agreements and missions abroad. The other tools listed previously are rarely used. To some extent, this shows that the objectives of Brazilian subunits focused on economic interests (an elementary goal of paradiplomacy), such as promotion of local businesses, investment attraction and foreign trade stimulation. Political goals are unusual.

In Europe, on the other hand, although there may be some countries that limit the formal power of their sub-states to operate abroad, it is clear that they perform more diplomatic activities than Brazilian ones. This is particularly due to the advances in the regional integration process that has necessitated that they improve their international participation to defend their interests. Finally, Brazilian paradiplomacy occurs on a limited basis, considering the tools used, human and material resources, organisation, structure and functioning. On the other hand, European paradiplomacy has achieved their 'third wave' or what Criekemans describes as a defined 'foreign policy', a higher degree of institutional agreements, investments in new forms of diplomacy (like 'public diplomacy'), professionalisation, and expansion and deepening of co-operation (Criekemans 2008: 3435). Taking this advanced stage into account, it is more than significant to question the intentions behind it. 
Given their stages in the process, it is possible to conclude that European countries and Brazil do not promote paradiplomatic activities based on similar goals or conditions. These asymmetries challenge the perceptions and the basic principles about international co-operation, as this is based on genuine alliances, inclusive participation and mutual benefits rather than on an unequal power relationship. Having said that, what are the interests behind this kind of co-operation? What impacts or results are drawn from this co-operation? The present research aims to answer part of that question through the analysis of DC involving Brazil and some European countries.

\section{Brazil/Europe DIC}

In procedural terms, if Brazilian states and municipalities wish to establish technical co-operation partnerships with countries and international organisations, they must submit their projects to ABC-MRE, which will first check the Basic Agreement between Brazil and the international entity. Once the validity of the Agreement is confirmed, the projects can go further. Since no additional clauses are made in the obligations of the Basic Agreement or in its complement and, by consequence, no charges are applied to the national patrimony, these acts may be concluded without congressional approval. Such projects are then implemented through Complementary Agreements and Executive Programmes, and the negotiation and necessary referrals for ratification are done by the Ministry of Foreign Affairs. Ever since 2010, the International Acts Division of the Ministry of Foreign Affairs includes in its co-operation manual a reference to DIC and indicates procedures to guide sub-national governments. This is due to the increase in these activities in Brazil.

International technical co-operation is a tool for the development of technical capabilities, through the access and incorporation of knowledge, information, technologies, experiences and practices on a non-commercial basis in all areas of knowledge. Through technical co-operation, the beneficiaries have access to experience and expertise that aggregates the previously existing institutional and human capacity, which contributes to the development of the country. The projects presented in this area aim to enhance the exchange of knowledge, train and qualify institutions and individuals, and consult and train support programmes. Co-operation also occurs through technical missions, studies, and development of joint activities in order to solve a given problem.

To verify the details of Brazil/Europe co-operation, the international technical co-operation projects in the period between 1999 and 2014 were mapped and evaluated: 273 projects involving the participation of Brazilian states were identified. Of these 273 projects, 150 were bilateral co-operation agreements and 123 were multilateral agreements. The sectors prioritised in technical co-operation were the environment (23.5\%), economic development (18.7\%), social inclusion (17.6\%), public administration (15.4\%) and health (9.9\%). Regarding infrastructure, there were only 11 technical co-operation projects. On the other hand, the health sector was also highlighted in international technical co-operation at almost $10 \%$ of all analysed projects. The abovementioned data reflects what 
Brazilian subunits prioritise when they co-operate with other countries, with their top priority being economic development.

The most important information in this analysis refers to the relevance of European countries in the projects. Over the past 15 years, the countries with whom Brazil mainly seeks to collaborate are Japan (29\%), Germany (26\%), France (24\%), Canada (8.6\%) and Spain (6.6\%). The most targeted regions for co-operation over the years were the Brazilian Northeast and North regions.

Table 2 - Brazilian co-operation agreements with European States.

\begin{tabular}{|c|c|c|c|}
\hline & Germany & France & Spain \\
\hline$\%$ of projects & $26 \%$ & $24 \%$ & $6.6 \%$ \\
\hline Main Brazilian states & $\begin{array}{l}\text { Amazonas (12.8\%); } \\
\text { Pará (12.8\%); Acre } \\
(10.2 \%) ; \text { Bahia }(7.7 \%) ; \\
\text { Pernambuco }(7.7 \%)\end{array}$ & $\begin{array}{l}\text { Goiás (11.4\%); Pará } \\
(11.4 \%) ; \text { São Paulo } \\
(11.4 \%) ; \text { Minas Gerais } \\
(11.4 \%)\end{array}$ & Paraíba (20\%) \\
\hline Main sectors & $\begin{array}{l}\text { Economic development } \\
(43.6 \%) \text {; environment } \\
(20.5 \%) \text {; public } \\
\text { administration }(20.5 \%)\end{array}$ & $\begin{array}{l}\text { Economic development } \\
(50 \%) \text {; environment } \\
(25 \%) \text {; technology } \\
(16 \%)\end{array}$ & $\begin{array}{l}\text { Public administration } \\
(40 \%) \text {; economic } \\
\text { development }(20 \%) \text {; } \\
\text { tourism }(20 \%)\end{array}$ \\
\hline Regions & $\begin{array}{l}\text { North }(44.7 \%) \text { and } \\
\text { Northeast }(34.2 \%) \text {; } \\
\text { Southeast }(13.2 \%) \text {; } \\
\text { South }(7.9 \%) \text {; Midwest } \\
\text { (0) }\end{array}$ & $\begin{array}{l}\text { Southeast }(25.7 \%) \text {; } \\
\text { North }(22.8 \%) ; \\
\text { Northeast }(22.8 \%) \text {; } \\
\text { Midwest }(20.2 \%) \text {; South } \\
(8.5 \%)\end{array}$ & $\begin{array}{l}\text { Northeast }(70 \%) \text {; South } \\
(20 \%) \text {; Southeast } \\
(10 \%) ; \text { North }(0) ; \\
\text { Midwest (0) }\end{array}$ \\
\hline
\end{tabular}

Source: Created by the authors, based on the research results.

The data from the table above shows that Germany, France and Spain have diverse partnerships with Brazilian states and the themes of co-operation have also varied, ranging across economic development, environment, tourism, public administration and infrastructure. It is noteworthy that the North and Northeast regions (less developed and with poor paradiplomatic conditions) are those with which countries have signed more agreements. In fact, as already mentioned, Brazilian subunits are marked by strong asymmetries in their internal development. This is an incentive rather than a deterrent to act internationally, given that the signed projects can promote local development.

However, the internal fragilities observed in the Brazilian states, especially related to bureaucratic structure and qualified staff, make them more vulnerable to foreign actors' handling. In a survey sent by e-mail to 199 bureaucrats involved in international projects, it was demonstrated that $43.4 \%$ of Brazilian states act internationally without a previous plan or a defined strategy. This condition is even worse in the less developed regions (North and Northeast), as shown in Table 3. On the other hand, the more developed states (in the South and Southeast) have an active and planned international posture. Moreover, 
$68 \%$ and $59 \%$ of interviewees from the Midwest and Northeast regions, respectively, indicated that an international relations policy rarely or never exists in the states. A passive position and unplanned international action open space for the influence of foreign actors. According to $56 \%$ of respondents, the involvement of the Brazilian states in international relations occurs because of the pressure or direct contact of foreign entities - considering only the responses from the North and Northeast regions, this percentage rises to $60 \%$.

Table 3 - Brazilian states' international strategies (per region).

How does the state operate internationally

\begin{tabular}{|c|c|c|c|c|c|c|}
\hline Average & & South & Southeast & Midwest & North & Northeast \\
\hline Has an active posture and a defined strategy & $33.5 \%$ & $52 \%$ & $59 \%$ & $20 \%$ & $25.8 \%$ & $14.8 \%$ \\
\hline $\begin{array}{l}\text { Has an active posture but an unplanned } \\
\text { strategy }\end{array}$ & $43.4 \%$ & $39 \%$ & $33 \%$ & $44 \%$ & $45 \%$ & $51.8 \%$ \\
\hline $\begin{array}{l}\text { Has a passive posture, acts only on demand } \\
\text { and does not have a defined strategy }\end{array}$ & $23.1 \%$ & $9 \%$ & $8 \%$ & $36 \%$ & $29.2 \%$ & $33.4 \%$ \\
\hline
\end{tabular}

Source: Froio (2015).

In addition, the Northeast region has the highest percentage (48\%) of non-specific institutions dealing with international affairs. As mentioned by some interviewees, the existence of a specific administrative body for international relations makes the state better prepared to deal with foreign entities and attract opportunities abroad rather than being attracted by these institutions. The survey also highlighted other problems faced by the Brazilian states in general that impact DIC: lack of planning and defined international policy, lack of sufficient structure and staff, low interest or lack of political involvement of the authorities, lack of experience of the public officers, and also the absence of a dedicated budget. In the Southeast (Brazil's most developed region), 77\% answered that they have a satisfactory structure in this area while in the Midwest, North and Northeast regions, the positive results were only $12 \%, 16 \%$ and $10 \%$, respectively. A negative result concerning the qualification of the staff in charge of international affairs in these last three regions was also found. The percentage of respondents who said there is 'little or no staff preparation to deal with international issues' are: $28 \%$ in the Midwest, $32.5 \%$ in the North, $28.7 \%$ in the Northeast, 6\% in the South, and 0\% in the Southeast (Froio 2015).

Interviews with international project managers from the state of Paraíba (located in the Northeast region of Brazil) also gave relevant information. It has been reported that foreign institutions take control over co-operation processes, so that the rules of these organisms, in certain cases, overlap those of the Brazilian government; foreign governments do not understand the singularities of the region, population, culture and legislation, imposing conditions that are difficult to apply; there is still a lack of technical preparation of several local officials involved in the projects, which causes a vulnerability to negotiate 
foreign terms. In addition, Mónica Salomón (2012: 11) points out that, although Brazilian sub-national governments are taking part in South-South co-operation, most Brazilian DC follows a North-South vertical logic of donor and recipient, and the role of many Brazilian local institutions is merely to organise the co-operation actions offered by foreign governments.

All this data highlights the vulnerabilities of the vast majority of Brazilian states. It also becomes evident that DIC between Brazil and Europe occurs under unequal conditions. This asymmetry causes the situation described next.

In this scenario, what stands out is the commitment of the European countries to invest in international co-operation projects with Brazilian entities. What are the consequences of many years of influence?

This prevailing presence becomes a reference for Brazilian subunits. Either projects are constantly renewed or new proposals with the same country emerge. The authorities themselves seek to maintain this partnership, which is their safest option, especially for the poorest Brazilian states, whose low resources made them unable to envisage new horizons and to diversify partnerships and projects. As a result, alliances are constantly reinforced, and competition is reduced. The President of the General Council of SeineSaint-Denis (France), Mr Stéphane Troussel, in his speech on DC, highlights the need to 'rapprocher.' This involves (i) portraying oneself as a reference; (ii) turning the NorthSouth co-operation logic around; (iii) a preoccupation with strengthening the partnership rather than with development co-operation alone; (iv) the development of a leading logic (Troussel 2013).

Some events demonstrate the consequences of this strategy. The agencies of subunits often report the co-operation agreement to the Brazilian Federal Government only after signing it. Some of these activities are characterised by (i) agreements that are signed without the existence of an earlier treaty framework, (ii) having a duplicate case and by (iii) the presumption of legality. These legal and procedural problems demonstrate both the authorities' unpreparedness and the local structures' vulnerabilities, resulting in cases of agreements signed without following Brazilian rules. In the interviews, it was reported that the local bureaucrats' lack of qualifications plus the foreign institutions' conditionalities make the external rules overlap with those of the Brazilian government.

Another example of power projection lies in the Brazilian legal reform that has been proposed in favour of standardising paradiplomatic activities. In 2005, a Constitutional Amendment (PEC No. 475/05) was presented asking that sub-national units be granted the right to promote and conclude agreements with foreign sub-national entities following prior authorisation. The proposal was rejected, and another attempt took place in 2006. The Complementary Bill (PLS No. 98/06) suggested an adjustment to allow states, municipalities and the Federal District, within its constitutional powers, to negotiate and make deals with other foreign subunits. These acts would have been subject to prior authorisation from the Ministry of Foreign Affairs. Once again, the bill was not approved.

For a recent proposal in 2013, representatives of sub-national governments took part in a series of meetings organised by the Under Secretariat for Federative Affairs of the 
Presidency of the Republic to create a presidential decree. The matter discussed involved the establishment of procedures for decentralised international technical co-operation activities. All deliberation around the proposal was completed, and they came to an agreement on the final text. What was most striking about this entire process was the subliminal influence of European countries. The countries were present at some meetings (through representatives), had an active voice in the debate, and were able to influence the content of part of the decree, particularly in relation to the ideas and concepts embodied in the final text.

For a long time, Brazil used the conceptual framework 'federal' (as federative diplomacy and international federative co-operation) to refer to its subunits - it is an allusion to the Brazilian federalist model. In 1995, the Ministry of Foreign Affairs built the idea of 'federative diplomacy' to refer to the international activity of the states and municipalities in order to give out the message that the diplomacy conducted by the central government was open to dialogue with the subunits and to have their international interests included in the national foreign policy. Later, during President Lula's administration, the idea that the central government sought to support paradiplomacy and to assist the subunits was strengthened through the creation of the term 'international federative co-operation', which denoted the idea of federative articulation.

However, the conceptual reference in the creation of the recent internal rules changed to 'decentralisation, highlighting that the new draft of presidential decree uses this terminology. One of the key reasons for this change was the co-operation protocols signed with Italy (2007) and France (2006). These protocols contributed two new ideas to the ongoing discussion. Firstly, the replacement of the federative concept with decentralisation something that is not part of the national culture, as the Brazilian subunits do not acquire the autonomy that the term might suggest and is present in several European countries. Secondly, the incorporation of civil society in this process - unprecedented for Brazilian diplomacy at all levels, since international affairs are traditionally shut out of society.

In the reports concerning preparatory meetings that led to the draft of the presidential decree, it is clear that Brazilian subunits do not feel fully comfortable with the use of 'decentralised' terminology. However, it was accepted for pragmatic reasons, since the first two internal rules on the subject (Protocols of Decentralised Cooperation with France and Italy) were made using this concept. Thus, it was understood that the next legal standards should not contradict the protocols' terminology, as they would hinder federal government internal approval. Such examples show the fragility of Brazilian states' paradiplomacy and the projection of interests and interference of European countries. The participation of European countries (especially France) in official meetings of the federal government were often focused on publicising actions and forcing partnerships (seen as a form of pressure). In one such meeting, these foreign participants criticised the presidential decree model in progress and even suggested other terminology, such as 'territorial co-operation.'

In sum, that the paper demonstrated: (1) bilateral co-operation with European countries is predominant within Brazilian decentralised technical co-operation (mainly with 
Germany, France and Italy); (2) Brazil's less developed regions have the largest number of agreements with European countries; (3) the survey has shown the critical paradiplomatic environment of the vast majority of Brazilian states (marked by passivity, absence of a defined strategy to negotiate with foreigners, lack of structure and qualification of the paradiplomatic staff) that make them vulnerable to pressure from foreign entities; (4) interviews with international project managers from the state of Paraíba showed that DIC is marked by the impositions of foreign institutions; (5) the recent attempt to draft a decree to standardise DIC showed European countries' interference, determining its conceptual framework; (6) European countries' participation in Brazil's Presidency of the Republic meetings to deal with issues of DC was also marked by propaganda and the attempt to establish new co-operation.

These results show, firstly, the asymmetry problem and the power projection of the European countries, since they predominate in Brazilian states' decentralised technical co-operation, even creating a dependency relationship in some cases. It also shows their power of influence and agenda interference, determining the conceptual references of domestic rules. The inability of many Brazilian states to participate actively in co-operation, due to economic, political and institutional fragility, has led to unequal co-operation and hierarchical partnerships that expose the difficulties of a North-South co-operation, full of conditionalities, impositions and centralism.

The benefits that international technical co-operation can bring to Brazil and its subunits is not contemplated in our discussion. In spite of this, it has been our intention to call for new reflections on the matter and to advance by questioning the influence of powerful countries, as well as by analysing the extent of their harm (or lack thereof).

The reality is that most Brazilian states need international partnerships to boost development. The precarious internal conditions coupled with the lack of institutional support is what exposes Brazil to the power and influence of other countries. The fact that most Brazilian subunits operate without clear international planning and are, thus, constantly unprepared, has resulted in weakened paradiplomacy, where foreign countries define rules and values, lead projects, and impose their own terms.

\section{Conclusions}

A deeper global interdependence has provided a rapid impact of world events on substate actors' internal environment, leading them to search for alternatives to respond to external suits. Hence, there has been a growing interest and direct participation of internal actors in international affairs - a phenomenon well known as paradiplomacy.

Such international operations may reflect sub-nationals' interests in implementing their own policies or even a broader strategy for power projection, since co-operation could intensify political and economic relations and propagate the image of the state as a whole - states gain visibility and a strengthened leadership position and project values that form part of their image. In other words, paradiplomacy serves to gain power projection, that is, a power of persuasion and influence, as could be observed in the case of DIC between Brazil and European countries. 
During the period under review (1999-2014), the relevance of European countries as partners in Brazil's DC projects was verified. Europe's prevailing presence becomes a reference for Brazilian subunits, especially for the poorest Brazilian states, whose low resources hinder them from investing in new partnerships. In fact, in order to better understand the problem under analysis, it is important to reinforce that the technical conditions (or stages) of Brazilian and European paradiplomacy are very dissimilar. It is remarkable that there is a significant difference in terms of capacity, human and material resources, organisation, structure and functioning. European paradiplomacy has achieved its 'third wave,' marked by a high number of institutional agreements, investments in new forms of diplomacy, a high level of professionalism, and the expansion of co-operation agreements worldwide. Meanwhile, Brazilian states act internationally without previous planning or a defined strategy, being in most cases more reactive than active and attracted by foreign countries' influence.

The empirical research, which mapped the Brazil-Europe international co-operation agreements, brought interviews and analysed meetings official reports, showed how and in what way European countries have acted through the DIC. Over the past 15 years, they have intensified and strengthened their presence and, despite co-operation aimed at local development and exchange of mutual benefits, it can also alter domestic behaviour. In short, many agreements were signed without following Brazilian domestic legislation and procedures; the diversification of partnerships has been made unfeasible due to the precarious paradiplomatic conditions observed in several Brazilian states, hindering an active participation, reinforcing the European presence, and making states vulnerable to the external influence; the participation of the European countries in official meetings of the federal government has caused significant interference, impacting the construction of domestic laws, and changing historical conceptual beliefs and references related to the Brazilian federalist model - an example of agenda interference.

The inability of many Brazilian states to pursue their interests in international relations is related to their economic, political and institutional conditions (asymmetries), resulting in unequal co-operation, which within North-South partnerships causes conditionalities, impositions, and centralism.

In conclusion, what are the consequences of this scenario? The answer is the consolidation of the power projection, as pointed out in all the examples above. In fact, European countries, and their subunits, are gaining visibility, strengthening their leadership position and projecting values that form part of their image in the world. The overall conclusion is that, even in DC agreements, power relations are crucial in determining the results of co-operation.

\section{Notes}

1 As Keating (1999: 6) points out: 'Paradiplomacy is part of a broadening of the universe of international affairs, in which states are no longer the sole actors. Regions operate alongside firms, trade unions, social movements and transnational organizations like Greenpeace or Oxfam. This universe is complex, fragmented and unstructured.' 
2 Other terminologies are used, such as: non-central governments, subunits, territorial subunits, local/ regional governments.

3 Some relevant authors on the theme: Ivo D. Duchacek (1970, 1986, 1990), Ivo D. Duchacek and Daniel Latouche (1988), Hans J. Michelmann, and Panayotis Soldatos (1990), John Kincaid (1990), Earl Fry (1988), Guy Lachapelle and Stéphane Paquin (2005).

4 Although the Cotonou Agreement is less specific about DC, as there is no section in the agreement that details the subject, as occurred in the previous Lomé Convention, the comprehension of what DC is has not changed.

5 The waves' frame proposed by Criekemans is, in some way, inspired by Duchacek's geopolitical dimensions typology: (1) transborder regional paradiplomacy; (2) transregional (or macroregional) and paradiplomatic contacts; (3) global paradiplomacy (Duchacek 1990: 16).

6 Brazilian paradiplomacy develops under common competences, which includes, for example, the areas of health care, environment, culture and education (Cf. Brazil 1988: Title VIII).

7 Data from the Scientific Initiation Research Programme coordinated by Professor Liliana Ramalho Froio (Federal University of Paraíba/Brazil) from 2015 to 2016 and entitled 'The role of paradiplomacy in the development of subnational governments: An analysis of the state of Paraíba / Brazil' - still not published.

8 The duplication occurs when there is an existing framework agreement between the central government, but the federal units have signed another agreement. The presumption of legality is the perception of subnational governments that the agreement produces legal effects as a result of their signature and would be automatically bound to the agreements signed by the central government, exempting the required formalities.

9 This semantic change should be understood in practical terms, as the theoretical level of a federal system normally involves more autonomy than that of decentralised ones (see Rougemont 1994).

10 All the meetings' reports are available on the Portal Federativo website.

\section{References}

Acuto, Michele. 2013. 'City leadership in global governance.' Global Governance 19: 481-498.

Brazil. 1988. Federal Constitution. 5 October.

Coll, Josep M. 2015. 'Cities [sic] emerging soft power: 5 key advantages for improved global governance.' RevistaCIDOB - Opinión [online] 332. At https://www.cidob.org/en/publications/publication_series/opinion/seguridad_y_politica_mundial/cities_emerging_soft_power_5_key_advantages_for_improved_global_governance [Accessed on 12 September 2017].

Criekemans, David. 2008. 'Are the boundaries between paradiplomacy and diplomacy watering down?' Paper delivered at World International Studies Committee - 2nd Global International Studies Conference. Ljubljana, Slovenia, 23-26 July.

Duchacek, Ivo D. 1970. Comparative Federalism: The Territorial Dimensions of Politics. New York: Holt, Rinehart and Winston.

1986. The Territorial Dimension of Politics With, Among and Across Nations. Colorado: Westview Press.

1990. 'Perforated Sovereignties: Towards a typology of new actors in internacional relations.' In Hans Michelmann and Panayotis Soldatos (eds), Federalism and International Relations: The Role of Subnational Units. New York: Oxford University Press, pp. 1-33.

Duchacek, Ivo, Daniel Latouche and Garth Stevenson. 1988. Perforated Sovereignties and International Relations: Trans-Sovereign Contacts of Subnational Governments. Connecticut: Greenwood Press. 
Elazar, Daniel J. 1966. American Federalism: A View from the States. New York: Thomas R Crowell Company.

1987. Exploring Federalism. Alabama: University of Alabama Press.

Esteves, Paulo and Manaíra Assunção. 2014. 'South-South co-operation and the international development battlefield: Between the OECD and the UM.' Third World Quarterly 35 (10): 1775-1790.

Feldman, Elliot J and Lily G Feldman. 1984. 'Impact of federalism on the organization of Canadian foreign policy. Publius 14 (4): 33-59.

Freres, Christian. 2000. 'The European Union as a global "civilian power": Development co-operation in EU-Latin American Relations.' Journal of Interamerican Studies and World Affairs 42 (2): 63-85.

Fry, Earl. 1988. 'Trans-sovereign relations of the American states.' In Ivo Duchacek, Daniel Latouche and Garth Stevenson (eds), Perforated Sovereignties and International Relations: Trans-Sovereign Contacts of Subnational Governments. Connecticut: Greenwood Press, pp. 53-67.

Froio, Liliana Ramalho. 2015. Paradiplomacia e o Impacto da Alternância de Governos na Atuação Internacional dos Estados Brasileiros. PhD Thesis, University of Pernambuco, Brazil.

Grosfoguel, Ramón. 1995. 'Global logics in the Caribbean city system: The case of Miami'. In Paul L Knox and Peter J Taylor (eds), World Cities in a World-System. Cambridge: Cambridge University Press, pp. 156-170.

Hafteck, Pierre. 2003. 'An introduction to decentralized co-operation: Definitions, origins and conceptual mapping.' Public Administration and Develeopment 23: 333-345.

Heine, Jorge. 2013. 'From club to network diplomacy'. In Andrew F Cooper, Jorge Heine and Ramesh Thakur (eds), The Oxford Handbook of Modern Diplomacy. Oxford: Oxford University Press.

Jones, Barry and Michael Keating. 1995. The European Union and the Regions. Oxford: Clarendon Press.

Keating, Michael. 1999. 'Regions and international affairs: Motives, opportunities and strategies.' In Francisco Aldecoa and Michael Keating (eds), Paradiplomacy in Action. London: Frank Cass, pp. 1-16.

Keohane, Robert and Joseph Nye. 1971. Transnational Relations and World Politics. Cambridge: Harvard University Press.

1989. Power and Interdependence. Cambridge: Harper Collins.

Kincaid, John. 1990. 'Constituent diplomacy in dederal polities and the nation-state: Conflict and co-operation.' In Hans J Michelmann and Panayotis Soldatos (eds), Federalism and International Relations. Oxford: Clarendon Press, pp. 54-75.

Knox, Paul L. 1995. 'World cities in a world-system.' In Paul L Knox and Peter J Taylor (eds), World Cities in a World-System. Cambridge: Cambridge University Press, pp. 3-20.

Kuznetsov, Alexander S. 2015. Theory and Practice of Paradiplomacy: Subnational Governments in International Affairs. New York: Routledge.

Lachapelle, Guy and Stéphane Paquin. 2005. Mastering Globalization: New Sub-states' Governance and Strategies. London and New York: Routledge.

Loaeza, Soledad. 2014. 'Germany's Latin America Policy: A success of soft power' 29 August. At http://www.soledadloaeza.com.mx/?p=639 [Accessed on 23 April 2018]. 
McHugh, James T. 2015. 'Paradiplomacy, protodiplomacy and the foreign policy aspirations of Quebec and other Canadian provinces.' Canadian Foreign Policy Journal 21 (3): 238-256.

Mello e Souza, André. 2014. 'Repensando a cooperação internacional para o desenvolvimento' In André Mello e Souza (eds), Repensando a Cooperação Internacional para o Desenvolvimento. Brasília: IPEA, pp. 11-29.

Michelmann, Hans and Panayotis Soldatos (eds). 1990. Federalism and International Relations: The Role of Subnational Units. New York: Oxford University Press.

Monnet, Jean. 1976. Mémoires. Paris: Fayard.

Neves, Miguel Santos. 2010. 'Paradiplomacy, knowledge regions and the consolidation of "soft power." JANUS.NET e-journal of International Relation 1: 10-28.

Nye, Joseph. 2008. 'Public diplomacy and soft power.' The ANNALS of the American Academy of Political and Social Science 616 (1): 94-109.

2011. The Future of Power. New York: PublicAffairs.

Portal Federativo [online]. Eventos e Reuniões. At http://www.portalfederativo.gov.br/articulacao-federativa/assessoria-internacional/eventos-e-reunioes [Acessed on 8 July 2019].

Rodrigues, Gilberto Marcos Antônio. 2004. Política Externa Federativa: Análise de Ações Internacionais de Estados e Municípios Brasileiros. $\mathrm{PhD}$ Thesis, Pontifícia Universidade Católica de São Paulo (PUC-SP), Brazil.

Rougemont, Denis (ed). 1994. Dictionnaire International du Fédéralisme. Bruxelles: Bruylant.

Salomón, Mónica. 2012. 'Em que medida é possível integrar a Cooperação Descentralizada na dimensão Sul-Sul da política externa brasileira?' Mural Internacional 3 (2): 9-15.

Soldatos, Panayotis. 1990. 'An explanatory framework for the study of federated states as foreign-policy actors.' In Hans Michelmann and Panayotis Soldatos (eds), Federalism and International Relations: The Role of Subnational Units. New York: Oxford University Press, pp. 33-53.

Stren, Richard. 2008. 'International assistance for cities in low- and middle-income countries: Do we still need it?' Environment \& Urbanization 20 (2): 377-392.

Troussel, Stéphane. 2013. Speech. $4^{\text {ème }}$ Forum de L'Action Internationale des Collectivités - Cités Unies France. Paris, France, 1-2 July. At https://vialemonde93.net/IMG/pdf/Forum_action_des_CT.pdf. [Accessed on 8 July 2019].

\section{About the authors}

Liliana Ramalho Froio received her Ph.D. in Political Science from the Federal University of Pernambuco (UFPE, Recife, Brazil) in 2015. She is Full Professor of History of International Relations at the Department of International Relations of the Federal University of Paraíba (UFPB, João Pessoa, Brazil) and at the Postgraduate Program in Political Science and International Relations (PPGCPRI/UFPB). She was International Affairs Advisor at the Undersecretariat for Federative Affairs of the Presidency of the Republic of Brazil (2013-2014). Her research has focused largely on paradiplomacy and decentralised international co-operation, especially the international relations practices of Brazilian subnational states and municipalities. She coordinates the observatory 'Internacionalização Descentralizada em Foco' (www.idef-ufpb.com.br). 
Marcelo de Almeida Medeiros received his Ph.D. in Political Science from the Institut d'Études Politiques de Grenoble (1997) and his Habilitation Thesis from the Institut d'Études Politiques de Paris - Sciences Po (2010). He is Full Professor of Comparative International Politics at the Federal University of Pernambuco - UFPE (Recife, Brazil) and PQ-1C Research Fellow of the National Council for Scientific and Technological Development - CNPq (Brasilia, Brazil). He was Rio Branco International Relations Chair at St Antony's College, University of Oxford (2015), Visiting Scholar at the Institut d'Études Politiques de Paris - Sciences Po (2008-2009), and Simon Bolivar Political Science Chair of the Institut des Hautes Études de l'Amérique Latine - Université Sorbonne Nouvelle Paris III (2009).

\title{
Analisando a Assimetria na Cooperação Internacional Descentralizada: 0 Caso das Relações Subnacionais Brasil/Europa
}

\begin{abstract}
Resumo: O artigo analisa a cooperação internacional descentralizada entre o Brasil e a Europa, enfocando duas questões específicas que não são os principais objetivos da literatura especializada em estudos de paradiplomacia. Primeiro, como a cooperação internacional pode ser usada como uma ferramenta para projeção de poder. Segundo, os efeitos que a assimetria econômica, política e institucional entre os atores envolvidos nos acordos de cooperação produz sobre os resultados da cooperação. Para isso, utilizou-se uma ampla gama de documentos e dados (entrevistas, documentos oficiais, atas de reuniões e dados coletados com pesquisa aplicada a gestores públicos), relacionados à cooperação internacional desenvolvida entre o Brasil e os países europeus. As conclusões são de que, mesmo em acordos de cooperação descentralizada, as relações de poder são importantes para os resultados da cooperação.
\end{abstract}

Palavras-chave: cooperação internacional descentralizada; relações subnacionais; assimetria; Brasil; Europa.

Received on 8 July 2019, and approved for publication on 6 January 2020.

\section{(cc) BY-NC} https://creativecommons.org/licenses/by-nc/4.0/ 